\title{
OPEN \\ ACCESS \\ Using parallel regional- and local-scale initiatives to inform conservation management of rare wildlife: a case study of the dugong Dugong dugon in Sabah, Malaysia
}

\author{
L. Rajamani ${ }^{1,3, *}$, H. Marsh ${ }^{2}$ \\ ${ }^{1}$ Borneo Marine Research Institute, Universiti Malaysia Sabah, Locked Bag 2073, 88999 Kota Kinabalu, Sabah, Malaysia \\ ${ }^{2}$ James Cook University, Townsville, Queensland 4811, Australia \\ ${ }^{3}$ Present address: Centre for Marine and Coastal Studies, University Sains Malaysia, 11800 Pulau Pinang, Malaysia
}

\begin{abstract}
Obtaining the information needed to inform management strategies for rare wildlife species at appropriate scales is costly and logistically demanding. Using coastal aerial surveys we obtained qualitative information on the distribution and abundance of the dugong Dugong dugon at the geopolitical scale of the state of Sabah in east Malaysia. At a local scale, interview surveys and a monitoring program were carried out at 2 sites: Mantanani Island and Banggi Island. A total of 53 dugongs were observed from the air, concentrated around Labuan Island - Brunei Bay and Sandakan Bay. The interview reports and monitoring program indicated that the residents of Mantanani Island and Banggi Island had local knowledge of the distribution and abundance of dugongs and, thus, an ability to participate in monitoring at that scale. Dugong populations in Sabah are small and clumped, and urgently require management intervention at local scales in the regionally important habitats identified by the aerial surveys. This combination of regional- and local-scale initiatives has a more generic application in the monitoring of other rare species of wildlife.
\end{abstract}

KEY WORDS: Dugong $\cdot$ Sabah $\cdot$ Interview surveys $\cdot$ Aerial surveys $\cdot$ Threatened species

\section{INTRODUCTION}

Obtaining the information required to assist in the development of conservation management strategies for rare species of wildlife is challenging because of logistical difficulties and strong competition for the limited financial resources. Information at a geopolitical scale identifies key habitats and provides a context for the local-scale initiatives that are essential for effective conservation intervention. The challenge of optimizing initiatives across scales is greatest in developing countries, especially in countries that are biodiversity 'hotspots', where the competing demands on conservation management are urgent and complex.

The island of Borneo is home to flagship terrestrial mammals with high social values such as the orang utan, rhinoceros and elephants, and such species have been the focus of multiple conservation initiatives (e.g. Payne \& Andau 1997, Russon 2002, Fernando et al. 2003, Ancrenaz et al. 2004, WWF Malaysia 2008, Clements et al. 2009). In contrast, there have been fewer initiatives focused on marine species, including the dugong Dugong dugon, which is classified as Vulnerable to extinction at a global scale by the International Union for the Conservation of Nature (IUCN) (Marsh 2008) and is listed in Appendix 1 of the Convention on International Trade in Endangered Species (CITES) of Wild Flora and Fauna (CITES 2008).

Dugongs were considered rare and possibly extirpated in Malaysia until a spate of dugong stranding incidents was reported in Johor, Peninsular Malaysia, in 1999, generating significant media and public interest (Marsh et al. 2002, Rajamani et al. 2006). The Malaysian Department of Fisheries conducted preliminary 
aerial surveys off the southeast coast of Peninsular Malaysia and sighted 17 adult dugongs and 1 calf. A further 26 dugongs were observed during aerial surveys from 1999 to 2007 (Marsh et al. 2002, Affendi et al. 2005, Y. A. Affendi pers. comm. in 2008). The resultant renewed interest encouraged the Malaysian government to prioritize research on dugongs and seagrasses, including the research reported here, in the east Malaysian state of Sabah, part of the island of Borneo.

Sightings based on interview reports (Jaaman \& Lah-Anyi 2003) and 11 strandings reported from 2002 to 2007 confirm that dugongs still exist in the state. Most sightings and strandings have been close to the capital Kota Kinabalu and Labuan Island (Jaaman \& Lah-Anyi 2003). The dugong is fully protected by legislation in Sabah, specifically the Wildlife Conservation Enactment 1997 and Fisheries Act 1985. However, the dugong remains threatened due to incidental entangling in fishing nets, dynamite fishing, hunting and unsupervised tourism (Jaaman \& Lah-Anyi 2003, Jaaman et al. 2009, Rajamani 2009).

The present study aimed to develop and test costeffective techniques of assessing dugong populations in Sabah at local and regional scales, which could be used to inform conservation policy. Using coastal aerial surveys we obtained qualitative information on the distribution and abundance of dugongs at the geopolitical scale of the state of Sabah. At a local scale, interview surveys and a monitoring program were trialed at 2 sites: Mantanani Island and Banggi Island.
$6 \mathrm{~km})$, cross-shelf transects logistically challenging and prohibitively expensive at the survey intensity required to sample a small clumped population. Thus, we conducted standardized aerial surveys parallel to the coast to identify the areas of greatest dugong abundance in the inshore waters of Sabah. We surveyed $\sim 1448 \mathrm{~km}$ of coastline from the Sabah side of Brunei Bay to Sandakan, including the islands of Labuan, Banggi, Balambangan and Jambongan, twice (in 2003, and in 2005 to 2006 - the survey could not be completed in 2005 due to adverse weather conditions and had to be continued in 2006). The aircraft (4 seater Bell 206 JetRanger III helicopter or high-wing Cessna 172) flew approximately $1 \mathrm{~km}$ away from and parallel to the shore, guided by reference GPS readings. Dugongs were counted in strip transects on each side of the aircraft; the transects were demarcated by tape on the windows (both aircraft) and marks on the wing strut (Cessna 172). Transect width was $311 \mathrm{~m}$ (helicopter) or $222 \mathrm{~m}$ (fixed wing aircraft). The aircraft were maintained at a constant height of $213 \mathrm{~m} \mathrm{(700} \mathrm{ft;} \mathrm{helicopter)}$ and $274 \mathrm{~m}(900 \mathrm{ft}$ Cessna 172). Both aircraft flew at a constant speed (167 $\mathrm{km} \mathrm{h}^{-1}$ or 90 knots).

The survey crew consisted of the pilot, the survey leader at the front right of the aircraft, and 2 experienced observers: 1 on each side of the aircraft. Surveys were conducted only when the cloud cover was $<50 \%$ and the sea was calm $(<$ Beaufort 3$)$ and were timed to minimize the glare off the surface of the water from a low or mid-day sun (Marsh \& Sinclair 1989, Marsh 1995a). When dugongs were sighted, reports from the

\section{MATERIALS AND METHODS}

Study areas. Sabah covers an area of $74500 \mathrm{~km}^{2}$, with a coastline almost $1500 \mathrm{~km}$ long (Sabah ICZM Spatial Plan 1999). Sabah borders on the South China Sea to the west and the Sulu Sea to the northeast. The state's territorial waters extend 12 nautical miles offshore (Sabah ICZM Spatial Plan 1999).

The entire coastline was surveyed from the air, except for the Tawau district on the southeast coast adjoining Kalimantan; Tawau (near the Indonesian border) was omitted for logistical and funding reasons. Interviews and monitoring were carried out at 2 sites in Sabah, selected on the basis of interview reports by the local inhabitants of Banggi Island and Mantanani Island (Jaaman 1999, 2000, Jaaman \& Lah Anyi 2003, G. Elliott pers. comm.) (Fig. 1).

Aerial surveys. The continental shelf of Sabah is narrow, which makes short (4 to

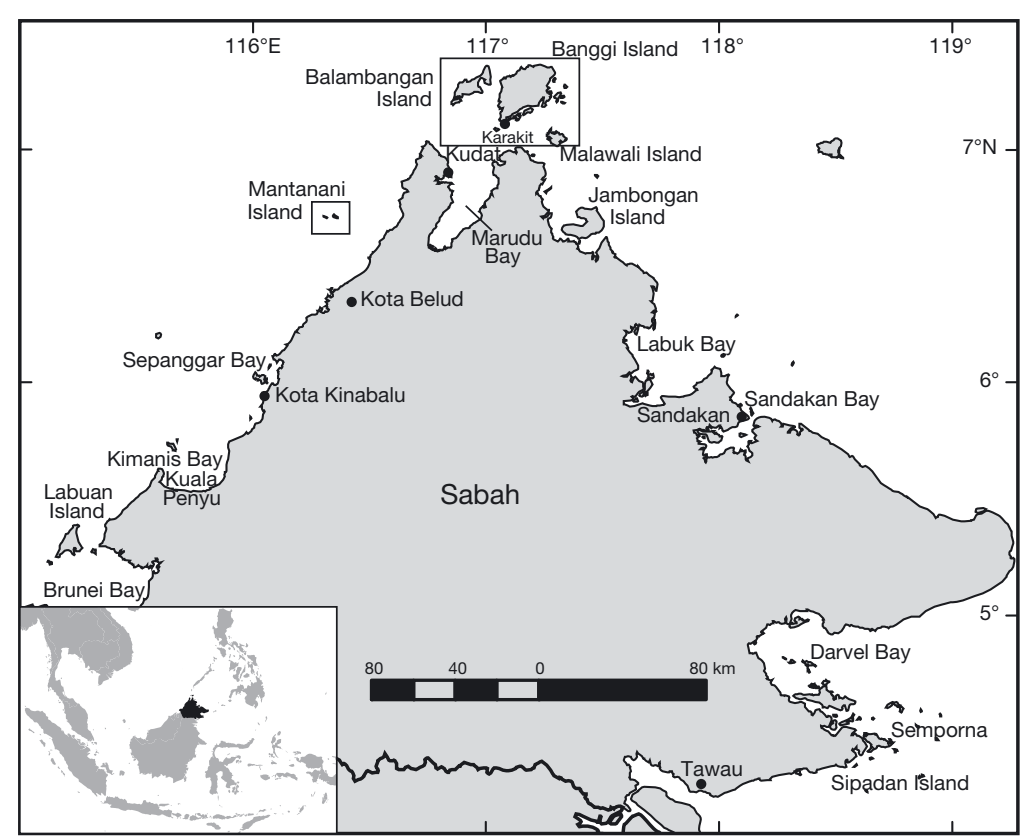

Fig. 1. Map of Sabah, Malaysia showing study areas (boxes). Banggi Island was the main focus of surveys and monitoring 
observers were delivered in a standardized format: dugong group size, number of calves and number at the surface. The survey leader recorded the sightings and information along with GPS co-ordinates, altitude and time. Cloud cover (oktas) was recorded at the beginning and end of each transect; Beaufort sea state, altitude, turbidity and GPS co-ordinates were recorded every $15 \mathrm{~min}$. The record of each flight was audiotaped for post-survey checking.

Interview surveys. Informal, semi-structured interviews using focus groups (Merton 1987, Berg 1989, Stewart \& Shamdasani 1990, Kitzinger 1994) were carried out at Banggi Island and Mantanani Island in 2002. Ethical and cultural considerations were taken into account in developing the approach and discussion questions (Table 1). The village head was always consulted before proceeding with the survey. We were almost always accompanied by a local member of the community to introduce ourselves. We accommodated local customs, such as dressing modestly in a predominantly Muslim community, and adopted mannerisms that were culturally acceptable, following advice from local group members and observations of participants.

We typically approached 4 to 8 fishermen or other interested members of the village and asked if they wanted to participate in a focus group immediately or by appointment. Individual interviews or interviews with 2 to 3 fishermen were conducted when a focus group could not be arranged. All interviews were conducted in the Malay language; a second person (such as our boatman) helped translate from the local Ubian language as required. If the participants gave their

Table 1. Questions asked during the interview surveys and the monitoring program

\footnotetext{
Interview questionnaire

1. Have you seen any of these animals here? (a poster of marine mammals is shown; if they identify dugongs then proceed to Question 2)

2. When did you see this dugong?

3. When was the last time you saw a dugong? Tell me the circumstances.

4. Where did you see this dugong?

5. How many animals did you see?

6. Is there a season when you see the dugong more often?

7. How many times did you see a dugong last year?

Monitoring program questionnaire

1. Have you seen any of these animals since I last saw you? If yes, what have you seen?

2. How many did you see? How many adults? How many calves?

3. Where and in what circumstances did you see them?

4. When did you see them?

5. Describe the area that you saw them in.

6. What were they doing when you saw them?

7. What were you doing when you saw them?
}

consent, the discussion was audio-taped for transcription; otherwise, notes were taken. Preliminary questions were asked to ascertain the validity of the interviewees' answers. We chose one question that an expert informant should be able to answer (What does a dugong's mouth look like?) and one that a fisher would be unlikely to know (What is the length of the gestation period of the dugong?). We interviewed 10 groups of fishermen and 13 individual fishermen in September 2002 on Banggi Island in the villages of $\mathrm{Kg}$. Lumais (Kg. = kampung = village), Kg. Lok Tohog, Kg. Kobong, Kg. Molleangan, Kg. Indalupi, Kg. Kaligau, Kg. Laksian, Kg. Garib (see Fig. 3). On Mantanani Island, we interviewed 9 groups and 2 individuals in February 2002 in the villages of $\mathrm{Kg}$. Padang and $\mathrm{Kg}$. Siring Bukit (see Fig. 4). The transcripts were analyzed qualitatively, and the major issues, such as dugong sightings, dugong stranding incidences and hunting incidences, were identified. We considered each group or individual interview to be a single unit.

Monitoring program. A community monitoring program developed at Banggi Island and Mantanani Island was simplified from the methods outlined by Marsh et al. (1997). We introduced our research in the middle of 2001 by arranging talks on dugongs and seagrasses for the community, and we asked the community if they would be interested in participating in dugong monitoring. The monitoring program lasted for 2 yr. The task was designed to accommodate the illiteracy of some members of the community; 2 to 3 key informants per village were asked to record incidences of dugong sightings, dugong strandings, dugong hunting and incidental catch on maps kept by a village member. In addition, L. Rajamani conducted follow-up interview surveys with fishermen in the same villages every $3 \mathrm{mo}$, to monitor the villagers' observations of dugongs (Table 1). Over the 2 yr period, 89 and 115 fishermen in Banggi and Mantanani, respectively, were involved in the monitoring program and the 3 monthly interview surveys. The villages monitored were the same as those involved in the interview surveys.

\section{RESULTS}

\section{Regional scale: identification of key dugong habitats using aerial surveys}

The survey flight times totalled $25.5 \mathrm{~h}$. Fifty-three dugongs Dugong dugon, including 9 calves, were observed, an average of $1.81 \pm 1.13$ dugongs per survey hour (Table 2). Seventeen sightings of 43 animals were made in September 2006; at other times, dugongs were mainly observed as solitary animals or in groups of 2. Twenty-six dugongs, including $9 \mathrm{cow} / \mathrm{calf}$ pairs, 
Table 2. Dugong dugon. Dugongs observed per hour during the aerial surveys of Sabah coastal waters

\begin{tabular}{|c|c|c|}
\hline Survey & Date & Dugongs observed $\mathrm{h}^{-1}$ \\
\hline 1 & Jul 2003 & 0.83 \\
\hline $2 \mathrm{a}$ & Dec 2005 & 0.20 \\
\hline \multirow[t]{2}{*}{$2 b$} & Sep 2006 & 4.40 \\
\hline & & Mean \pm SE $\quad 1.81 \pm 1.13$ \\
\hline
\end{tabular}

were seen apparently feeding in seagrass areas at depths of 5 to $7 \mathrm{~m}$ in Terusan Timur (Timur Strait), between Labuan Island and mainland Sabah (Fig. 2). The weather was exceptionally calm on that survey day. Beaufort sea state levels were between 0 and 1, which made visibility excellent. The surveys suggest that Labuan Island (29 dugongs sighted) and adjacent Brunei Bay (6 dugongs), Sandakan Bay (8 dugongs), Jambongan Island (3 dugongs) and Kudat (3 dugongs) supported the largest populations.

\section{Local scale: interview surveys and monitoring}

\section{Reliability of informants}

The interview surveys showed that about two-thirds of the fishermen could describe a dugong's mouth (64\% Banggi; 65\% Mantanani). The remainder were asked follow-up questions about a dugong's shape, e.g. whether it has a dorsal fin, and about feeding or swimming behavior. Most informants (74 and 100\% from Banggi Island and Mantanani Island, respectively) admitted to not knowing the length of a dugong's gestation period, although some Banggi Island informants (26\%) assumed the gestation period of a female dugong was close to that of a human. These answers suggested most of the informants were reliable. The transcripts of interviews in which respondents stated that they had never observed dugongs were excluded from further analysis.

\section{Banggi Island}

Focus groups/individual interviews. All fishermen had observed dugongs at Banggi Island. However, the animals were observed rarely: $48 \%$ (11/23 interviews) had observed dugongs only once in 2001, the reminder had not. Sightings were usually of 1 adult (58\%, 17/23 interviews) or of a mother and calf (31\% of interviews).
Sightings of 2 adults $(7 \%)$ or more were rare. A total of 29 sightings of live dugongs at Banggi Island have been reported since the 1960s (Table 3), mainly at Molleangan Island (6), Balambangan Island (6), in the $\mathrm{Kg}$. Kobong and Lok Tohog areas (4), at Panukaran Island (3), Karakit (3), Bangkawan Island ('Sibogo') (2) and Balak Island (1). The fishers also reported dugongs in other areas close to Banggi Island: Mandidarah Island, the south of Malawali Island and Kudat. Six stranding incidents, 4 instances of incidental catch and 2 hunting incidents were reported (Table 3). Collectively these reports total 41 dugong observations in the Banggi Island region between the 1960 s and the time of the interviews in 2002; some sightings may have been of the same animal.

Monitoring program. In 2001, there were 6 recorded sightings, 1 incidental capture and 1 hunting incident (Fig. 3): 1 dugong at Tiga Island and 1 near Kg. Maliyau were observed to have died due to hunting and incidental catch, respectively (Fig. 3). The other sightings were of a single dugong, which may be the same dugong spotted several times in the span of a few months in the south of the Molleangan area (close to the small islands of Molleangan Kecil, Molleangan Island and Pandanan Island). One cow and calf were observed in September 2001 near Molleangan Besar Island.

Thirteen sightings, 1 stranding incident and 1 hunting incident were recorded in 2002 (Fig. 3). At Tiga Island, a single adult dugong was spotted twice plus a mother and calf. An adult (possibly the same animal) was reported from Molleangan Island, Balak Island, Kg. Lok Tohog area, Panukaran Island and Pagassan Island. Two adult dugongs were spotted at Balak Island and also near Kg. Indalupi. Therefore, at least 5

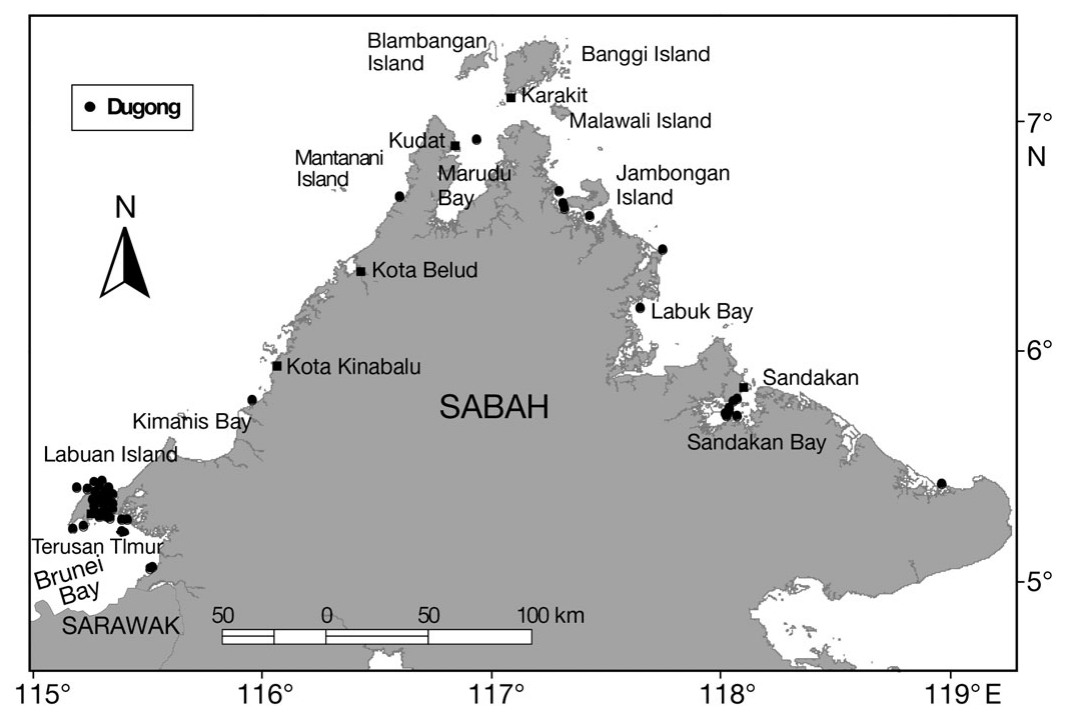

Fig. 2. Dugong dugon. Dugong sightings $(\bullet)$ during the aerial surveys in July 2003, December 2005 and September 2006 
Table 3. Dugong dugon. Summary of dugong observations reported by villagers from the interview surveys and monitoring (Mon.) program

\begin{tabular}{|lccccc|}
\hline \multirow{2}{*}{$\begin{array}{l}\text { Dugong } \\
\text { observations }\end{array}$} & $\begin{array}{c}\text { Interviews } \\
\text { (pre-2002) }\end{array}$ & $\begin{array}{c}\text { Mon. program } \\
(2001-2003)\end{array}$ & $\begin{array}{c}\text { Interviews } \\
(\text { pre-2002) }\end{array}$ & $\begin{array}{c}\text { Mon. program } \\
(2001-2003)\end{array}$ \\
\hline Sighting & 29 & 19 & 9 & $88^{\mathrm{a}}$ \\
Hunting & 2 & 2 & - & - \\
Stranding & 6 & 1 & 2 & - \\
Incidental catch & 4 & 1 & 2 & 1 \\
Total & 41 & 23 & 13 & 89 \\
and sightings were probably the same animal & & \\
\hline
\end{tabular}

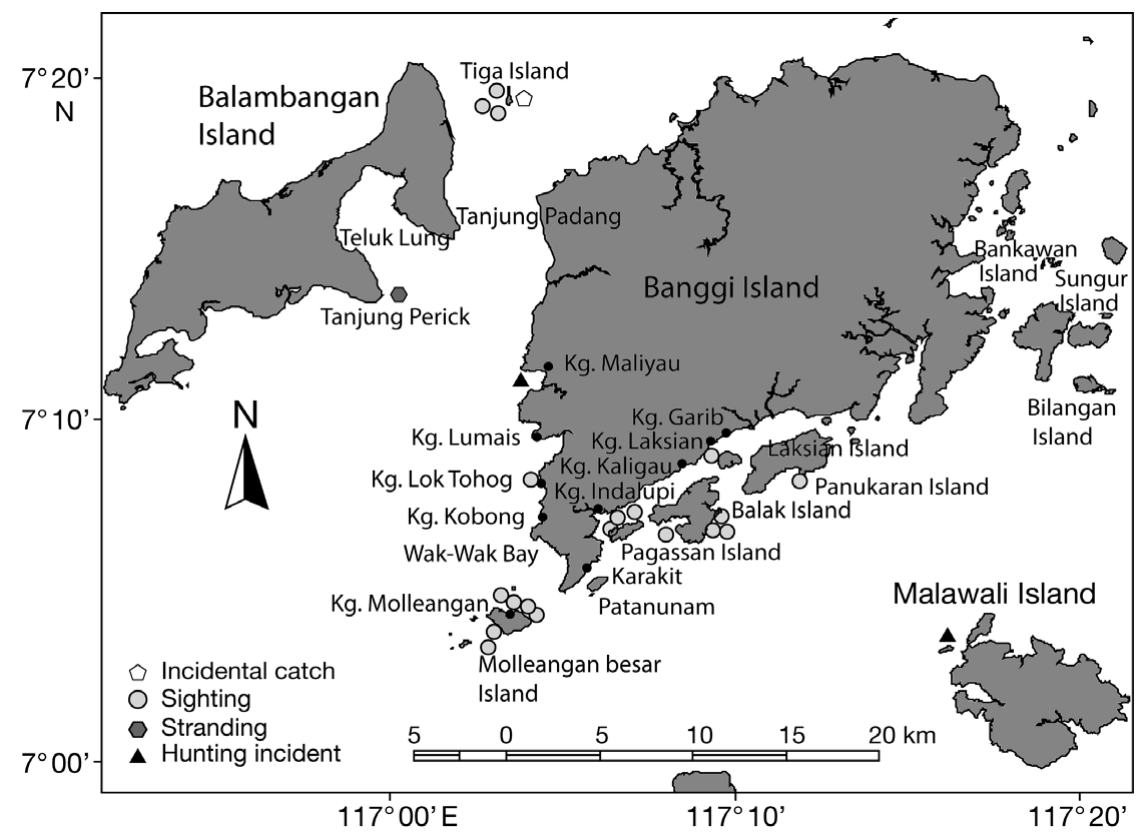

Fig. 3. Dugong dugon. Information obtained from the dugong monitoring program, for Banggi Island (2001 to 2003)

dugongs ( 3 adult dugongs and 1 mother and calf) were observed in the Banggi Island region in 2002.

\section{Mantanani Island}

Focus groups/individual interviews. Most fishermen interviewed in 2002 had observed dugongs (10/11 interviews). Reports included 9 sightings of single dugongs, 2 stranding incidents and 2 instances of dugongs incidentally caught (Table 3). All sightings were single adults.

Monitoring program. Between September 2001 and July 2003, 88 sightings of a single dugong and 1 incidental catch were recorded (Table 3). Most sightings were around Mantanani Besar Island, but 3 were recorded offshore, near oil rigs that were 10 to 15 nau- tical miles away. Most are likely multiple sightings of a single, adult male dugong that frequently interacted with people such as the villagers' children, Mantanani resort staff and tourists. There were 36 sightings off $\mathrm{Kg}$. Siring Bukit and 34 sightings off $\mathrm{Kg}$. Padang, all probably of the same dugong (Fig. 4). The dugong named 'Nicky' by the Mantanani resort staff, because of a characteristic $\sim 1$ to $2 \mathrm{~cm}$ deep nick found on the right fluke, frequented the region close to the villages of Siring Bukit and Padang, usually appearing between 15:00 and 18:00 $\mathrm{h}$ The dugong typically rested in the same shallow area near Kg. Padang's jetty (see Fig. 4), swam around the jetty, moved off and then returned. This behavior would continue for 2 to $3 \mathrm{~h}$. During this time, the villagers swam with the dugong and touched it. The animal has not been seen since 2007 .

A dugong trio (1 adult dugong, its calf and another adult) was observed in September 2001 off Kg. Siring Bukit. A mother and calf (possibly the same pair) were regularly observed from January 2002 to October 2002: 8 times in Kg. Siring Bukit, twice in Kg. Padang and once at Mantanani Kecil Island. A mother was observed with 2 calves in March 2003. One juvenile dugong was also observed near Mantanani resort, Mantanani Kecil and offshore near the police station (between Kg. Siring Bukit and Kg. Padang) in May and June 2003.

These observations suggest that at least 5 dugongs were resident or transient at Mantanani Island between 2001 and 2003. The dugongs were sighted very close to shore in sandy areas with patchy seagrasses of Halophila sp. and Halodule sp. The near-shore areas off the villages of $\mathrm{Kg}$. Siring Bukit and Kg. Padang appeared to be feeding and resting areas for dugongs.

\section{DISCUSSION}

Both the aerial surveys and the interviews with local fishers indicate that Sabah waters support a small and scattered population of dugongs Dugong dugon, predominantly in coastal areas in enclosed bays and on the lee of islands, a result typical for southeast Asia (Marsh et al. 2002). Labuan Island with adjacent 


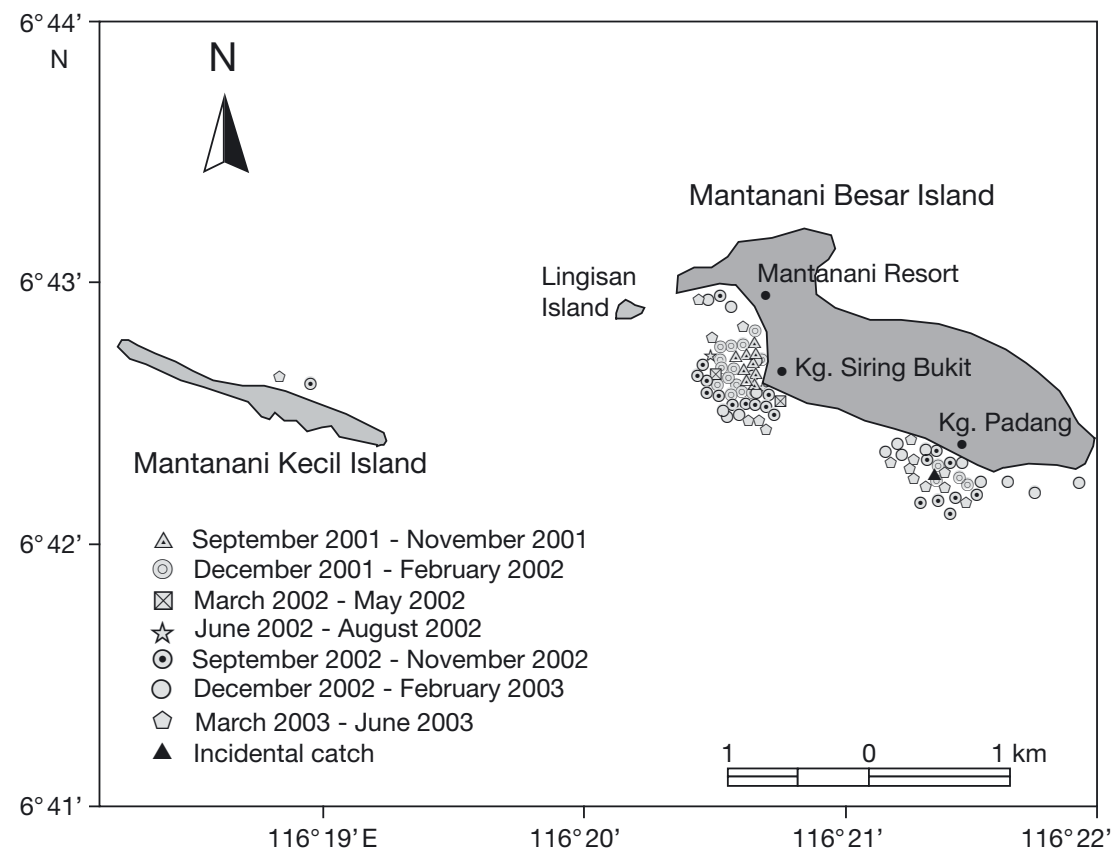

Fig. 4. Dugong dugon. Information obtained on dugong sightings and incidental catch from the monitoring program, for Mantanani Island (2001 to 2003) concern. In a companion study based on some of the interviews reported here, Rajamani et al. (2006) presented significant evidence of dugong hunting and dugong trade on Banggi Island and in the Kudat area more generally. Once the dugongs are caught they are either consumed locally or sold in regional centres. Dugongs are long-lived, with a low reproductive rate, a long generation time and high investment in each offspring (Marsh 1995b, 1999, Marsh et al. 2002). Modelling suggests that populations are unlikely to sustain anthropogenic mortality of $>2 \% \mathrm{yr}^{-1}$ (Marsh 1995b, 1999). Jaaman et al. (2009) estimate the dugong by-catch in Sabah waters to be 479 animals $\mathrm{yr}^{-1}$ (95\%, CI $=434$ to 528) (but see Moore et al. 2010). The results of our survey suggest that it is extremely unlikely that such mortality is sustainable. Regulations protecting dugongs in Sabah must urgently be enforced.

The present study enabled us to identify 'hotspots' of dugong abundance that should be a priority for policy makers. In particular, further protection of the dugong in the Labuan-Brunei Bay region will require international negotiations between Malaysia and Brunei and national negotiations between the Federal Territory of Labuan and the states of Sarawak and Sabah. Conservation initiatives at the local level could usefully be informed by the approach we tested using the villagers at Banggi and Mantanani Islands to obtain information. We demonstrated that it is possible to obtain information useful in conservation planning, such as dugong numbers, habitat and conservation issues, from fishers and other stakeholders. As pointed out by Rajamani et al. (2006), a community education program to assist local fishermen and other stakeholders to increase awareness and to promote an understanding of the laws and penalties involved in illegal dugong trade should be a high priority at a regional scale in Sabah. Also, the importance of the dugong/ seagrass habitat to fishery productivity should be emphasized, as Rajamani (2009) stressed that the community failed to see this significance.

The combination of regional- and local-scale initiatives outlined here is a cost-effective first step in the development of general conservation strategies for rare species of ecological concern, especially in developing countries. However, the key habitats identified by regional-scale surveys must now receive the conservation action indicated by local-scale trial approaches. 
Acknowledgements. A. R. Ridzwan had the vision that made dugong research possible in Sabah. The Ministry of Science, Technology and Environment Malaysia, the WWF-Malaysia and the Ocean Park Conservation Foundation, Hong Kong, funded the research. The Prince Bernhard Scholarship from WWF-Switzerland financially supported dugong and seagrass training in Australia for the senior author. Numerous villagers in Banggi Island and Mantanani Island donated time for the interview surveys and the monitoring program. I. Lawler and D. Kwan assisted with technical aspects of the aerial survey procedures. We acknowledge the assistance of the pilots from Sabah Air and Sabah Flying Club and our observers: E. Tangon, A. Cabanban, Y. L. Anyi, L. Khor, A. S. Ling, R. Ajam, Y. T. Kit, F. Masakin and J. Josim.

\section{LITERATURE CITED}

Affendi YA, Ooi J, Phang SM, Azhar H, Faedzul RR, Rosmadi F (2005) Dugongs in peril: the conservation and protection of dugongs in Johor, Malaysia. A scientific report for the United Nations Development Program, Kuala Lumpur, Malaysia, Universiti Malaya

Ancrenaz M, Calaque R, Lackman-Ancrenaz I (2004) Orangutan nesting behaviour in disturbed forests of Sabah, Malaysia: implications for nest census. Int J Primatol 25:983-1000

Berg BL (1989) Qualitative research methods for the social sciences. Allyn \& Bacon, Boston, MA

CITES (Convention on International Trade in Endangered Species) (2008) Appendices I, II and III. Available at: www.cites.org/eng/app/appendices.shtml (accessed: 1 Jan 2010)

Clements R, Rayan DM, Zafir AWA, Venkataraman A and others (2009) Trio under threat: Can we secure the future of rhinos, elephants and tigers in Malaysia? Biodivers Conserv 19(4):1115-1136

Fernando P, Vidya TNC, Payne J, Stuewe M and others (2003) DNA analysis indicates that Asian elephants are native to Borneo and are therefore a high priority for conservation. PLoS Biol 1(1):110-115

Jaaman SA (1999) Marine mammals and whale sharks recorded in Malaysia. Paper presented in Training Workshop on Marine Mammals and Whale Shark Research and Management, 15-18 March 1999, Universiti Malaysia Sabah, Kota Kinabalu

Jaaman SA (2000) Report on status and conservation of dugongs and inshore cetaceans in Sabah. Working paper in the Sulu-Sulawesi Marine Ecoregion project meeting, 26th September, Universiti Malaysia Sabah, Kota Kinabalu

Jaaman SA, Lah-Anyi Y (2003) Dugongs in East Malaysian waters (Dugong dugon Müller, 1776). ASEAN Review of Biodiversity and Environmental Conservation (ARBEC). Available at: www.arbec.com.my/dugongs

Jaaman SA, Lah-Anyi YU, Pierce GJ (2009) The magnitude and sustainability of marine mammal by-catch in fisheries in East Malaysia. J Mar Biol Assoc UK 89(5): 907-920

Editorial responsibility: Andrew Read, Beaufort, North Carolina, USA
Kitzinger J (1994) The methodology of focus groups: the importance of interaction between research participants. Sociol Health Illn 16:103-121

Marsh H (1995a) Fixed-width aerial transects for determining dugong population sizes and distribution patterns. In: O'Shea TJ, Ackerman BB, Percival HF (eds) Population biology of the Florida manatee. US Department of the Interior, National Biological Service, Washington, DC, USA. Inform Tech Rep 1:56-62

Marsh H (1995b) The life history, pattern of breeding and population dynamics of the dugong. In: O'Shea TJ, Ackermann BB, Percival HF (eds) Population biology of the Florida manatee. US Department of the Interior, National Biological Service, Washington, DC, USA. Inform Tech Rep 1:75-83

Marsh H (1999) Reproduction in sirenians. In: Reynolds JE, Twiss JR (eds) Marine mammals. Smithsonian Institution Press, Washington, DC, p 243-256

Marsh H (2008) Dugong dugon. In: IUCN 2009. IUCN Red List of threatened species, Vers 2009.2. Available at: www. iucnredlist.org (accessed 1 Jan 2010)

Marsh H, Sinclair DF (1989) An experimental evaluation of dugong and sea turtle aerial survey techniques. Aust Wildl Res 16:639-650

Marsh H, Harris ANM, Lawler IR (1997) The sustainability of the indigenous dugong fishery in Torres Strait, Australia/Papua New Guinea. Conserv Biol 11:1375-1386

Marsh H, Penrose H, Eros C, Hughes J (2002) Dugong status reports and action plans for countries and territories. UNEP early warning and assessment report series. The World Conservation Union, Gland

> Merton RK (1987) The focused interview and focus groups: continuities and discontinuities. Public Opin Q 51: $550-566$

Moore JE, Cox TM, Lewison RL, Read AJ and others (2010) An interview-based approach to assess marine mammal and the sea turtle captures in artisanal fisheries. Biol Conserv 143:795-805

Payne J, Andau M (1997) The orangutan in Sabah-An endangered species. J Wildl Conserv Manag Sabah 1: $40-46$

Rajamani L (2009) The conservation biology of the dugong (Dugong dugon) and its seagrass habitat in Sabah, Malaysia: a basis for conservation planning. PhD thesis, Universiti Malaysia Sabah, Kota Kinabalu

- Rajamani L, Cabanban AS, Ridzwan AR (2006) Indigenous use and trade of dugong (Dugong dugon) in Sabah, Malaysia. Ambio 35:266-268

Russon AE (2002) Return of the native: cognition and site-specific expertise in orangutan rehabiliation. Int J Primatol 23:461-478

Sabah ICZM Spatial Plan (1999) The ICZM Spatial Work Plan Group, Sabah. Sabah ICZM Task Force, Town and Regional Planning Department, Kota Kinabalu, Sabah

Stewart DW, Shamdasani PN (1990) Focus groups: theory and practice. Sage, Newbury Park

WWF-Malaysia (2008) Species. Available at: www.wwf.org. my/about_wwf/what_we_do/species_main/index.cfm (accessed 21 May 2008)

Submitted: January 5, 2010; Accepted: August 25, 2010

Proofs received from author(s): October 24, 2010 